\title{
PEMANFAATAN RUMPUT DAN KAYU BAKAR UNTUK KEBUTUHAN SUBSISTEN MASYARAKAT DI TAMAN NASIONAL GUNUNG MERBABU (Utilization of Grass and Fuel Wood for Community Subsistence Needs in Gunung Merbabu National Park)
}

\author{
Ayu Kurnia Aissiyah*, Lies Rahayu Wijayanti Faida, dan Much. Taufik Tri Hermawan \\ Program Studi Pascasarjana Ilmu Kehutanan, Universitas Gadjah Mada, Yogyakarta. \\ *Penulis korespondensi. Tel: 081326882510. Email: ayoe_kurnia@ yahoo.com.
}

\author{
Diterima: 31 Maret 2018
}

Disetujui: 12 September 2018

\begin{abstract}
Abstrak
Pemanfaatan rumput dan kayu bakar oleh masyarakat sekitar pada Taman Nasional Gunung Merbabu (TNGMb) tidak sejalan dengan zonasi taman nasional. Pada penelitian ini telah dilakukan berupa kajian intensitas pemanfaatan rumput dan kayu bakar dari kawasan TNGMb melalui identifikasi pengaruh antar faktor pada aktivitas pemanfaatan rumput dan kayu bakar oleh masyarakat serta identifikasi unsur pembentuk akses masyarakat dalam pemanfaatan rumput dan kayu bakar yang berasal dari kawasan TNGMb. Penelitian dilakukan di wilayah TNGMb dengan mengambil lokasi sampel di Dusun Godang, Guwolelo, Batur, dan Sembungan. Tipe penelitian yang digunakan adalah metode kombinasi. Pengumpulan data dilakukan melalui observasi lapangan, kuesioner, wawancara, dan penelusuran dokumen. Metode kuantitatif disajikan dalam bentuk statistik diskriptif (peta, distribusi frekuensi) dan analisis jalur. Metode kualitatif menggunakan analisis akses. Hasil penelitian menunjukkan bahwa intensitas pemanfaatan rumput dan kayu bakar di TNGMb di lokasi sampel tergolong sedang cenderung tinggi (63 kali per hari untuk rumput dan 41 kali per minggu untuk kayu bakar). Dalam kaitannya terhadap faktor pengelolaan lahan maka faktor budaya berpengaruh sebesar $91 \%$, faktor ekonomi berpengaruh sebesar 17,8\%. Faktor ekonomi menjadi faktor mediasi antara faktor budaya dan faktor pengelolaan lahan, serta terukur secara bersama-sama berpengaruh terhadap faktor pengelolaan lahan sebesar 49,2\%. Unsur pembentuk akses masyarakat sekitar kawasan dalam pemanfaatan rumput dan kayu bakar bersifat sederhana atau konvensional.
\end{abstract}

Kata kunci: pemanfaatan rumput, kayu bakar, zonasi taman nasional, komunitas, hutan, faktor budaya, faktor ekonomi, pengelolaan lahan.

\begin{abstract}
Grass and fuel wood utilization by community around Gunung Merbabu National Park (GMNP) was inconsistent with national park zoning. This research have been done by evaluating of the intensity of grass and fuel wood derived from GMNP, according to identify the effect between factors at grass and fuel wood utilization by community and determining of the community access pattern in grass and fuel wood utilization. The research study was implemented in GMNP area, which sample locations were Gondang, Guwolelo, Batur, and Sembungan villages. The method used for the research was a combined research method. Data collection was conducted by field observation, interview, questionnaires and document analysis. Quantitative method was presented in descriptive statistic (map, frequency distribution) and path analysis results. Qualitative method was conducted by access analysis. The results showed that intensity grass and fuel wood utilization in GMNP in sample location was in the middle to high trend categories (63 times per day for grass and 41 times per week for fuel wood). Affect to the land management factor, it has been known that the contribution of the cultural factor was in $91 \%$ and the economic factor was in $17.8 \%$. Economic factor become intervening factor between cultural factor and land management factor and it was evaluated in 49.2\%. Community access structure in grass and fuel wood utilization was simple or conventional.
\end{abstract}

Keywords: community, national park, grass, fuel wood, forest, economic factor, cultural factor. land management.

\section{PENDAHULUAN}

Taman Nasional Gunung Merbabu \pm seluas 5.725 ha terletak di antara Kabupaten Semarang, Boyolali, dan Magelang Provinsi Jawa Tengah. Taman Nasional Gunung Merbabu (TNGMb) merupakan kawasan konservasi yang dikelola pemerintah yang berfungsi melindungi keanekaragaman hayati dengan tetap memperhatikan kesejahteraan masyarakat di sekitar kawasan (Anonim, 2014). Taman nasional dikelola dengan pembagian wilayah pengelolaan (sistem zonasi). Saat ini seringkali terjadi overlapping antara kepentingan pengelolaan dengan kepentingan masyarakat. Salah satunya adalah aktivitas pemanfaatan rumput dan kayu bakar yang tidak sejalan dengan sistem zonasi. Pengambilan rumput dan kayu bakar oleh masyarakat sudah diakomodasi dalam zona tradisional dan zona pemanfaatan, namun seringkali aktivitas tersebut 
sampai dengan zona rimba dan zona inti yang merupakan zona perlindungan keanekaragaman hayati. Hal ini juga terjadi di kawasan TNGMb dan kawasan penyangganya sejak lama termasuk yang menjadi bahan kajian sebelum kawasan ini ditetapkan taman nasional (Gunawan, 2013)

Ketersediaan sumber daya pada kawasan taman nasional yang tidak seimbang dengan besarnya permintaan oleh masyarakat sekitar, menimbulkan konflik kepentingan. Hal ini disebabkan oleh tingginya kebutuhan akan rumput dan kayu bakar yang berasal dari kawasan. Hastuti (2010) menyebutkan bahwa dari 310 responden yang berada di dusun-dusun sekitar kawasan TNGMb sebanyak 97\% memanfaatkan sumber daya alam berupa rumput sebagai pakan ternak dan 73\% mengambil kayu bakar dari dalam kawasan TNGMb. Masyarakat yang tidak memanfaatkan rumput sebagai pakan ternak, menggunakan rumput sebagai pupuk organik untuk tanaman pertaniannya. Dengan kata lain bahwa hampir seluruh masyarakat yang berbatasan langsung dengan kawasan memanfaatkan rumput dan kayu bakar. Gambaran serupa terkait pemanfaatan hasil alam di kawasan hutan juga telah dilaporkan di Nepal (Adhikari dkk., 2003) dan Kamboja (Clements dkk., 2014). Steele dkk., (2015) telah menguraikan aspek yang terjadi pada kasus-kasus komunitas di sekitar hutan berupa dampak ekologi ketergantungan pemenuhan kebutuhan hidup, tingkat pengetahuan ekologi lokal dan tuntutan pasar dari pengambilan hasil hutan non kayu dari hutan.

Penelitian ini bertujuan mengetahui intensitas pemanfaatan rumput dan kayu bakar di kawasan $\mathrm{TNGMb}$ dan mengidentifikasi pengaruh antar faktor pada aktivitas pemanfaatan rumput dan kayu bakar oleh masyarakat, serta untuk mengidentifikasi unsur pembentuk akses masyarakat dalam pemanfaatan rumput dan kayu bakar.

\section{METODE PENELITIAN}

\section{Lokasi}

Penelitian dilakukan di kawasan Taman Nasional Gunung Merbabu, wilayah pengelolaan Resort Kalipasang, Semuncar, Wonolelo dan Wekas meliputi Dusun Gondang, Guwolelo, Batur dan Sembungan.

\section{Bahan dan Alat}

Bahan dan alat yang digunakan pada penelitian ini adalah peta zonasi tahun 2014, peta penutupan lahan, laporan kegiatan pada TNGMb, hasil-hasil penelitian, data statistik, GPS (Global Positioning System), komputer, perekam (digital voice recorder), kamera, pedoman wawancara, tally sheet, dan software path analysis.

\section{Metode Pengumpulan Data}

Pengumpulan data dilakukan dengan cara observasi lapangan, studi pustaka, kuesioner, dan wawancara. Diskripsi pengambilan sampel seperti disajikan pada Gambar 1.

\section{Analisis Data \\ Intensitas pemanfaatan rumput dan kayu bakar}

Analisis aktivitas masyarakat dalam kawasan (frekuensi, dan jarak tempuh masyarakat dalam memperoleh rumput dan kayu bakar yang kemudian ditumpang-susunkan dengan peta zonasi dan peta tutupan lahan). Kemudian data disajikan dalam bentuk peta aktivitas masyarakat di dalam kawasan, serta distribusi frekuensi (rendah, sedang, tinggi). Penyusunan distribusi frekuensi perlu dilakukan tahapan penyusunan data. Pertama melakukan pengurutan data-data terlebih dahulu sesuai urutan besarnya nilai yang ada pada data, selanjutnya diakukan tahapan berikut ini:

a. Penentuan jangkauan/range data. Jangkauan = data terbesar - data terkecil.

b. Penentuan jumlah kelas (k) dengan Rumus Sturgess $\mathrm{K}=1+3.3 \log \mathrm{n}$; di mana $\mathrm{k}=$ jumlah kelas, $\mathrm{n}=$ jumlah data

c. Penentuan panjang interval kelas.

$$
\text { Interval kelas }=\frac{\text { Nilai terbesar }- \text { Nilai terkecil }}{\text { Jumlah kelas }}
$$

Penentuan batas bawah kelas pertama. Tepi bawah kelas pertama dipilih dari data terkecil atau data yang berasal dari pelebaran jangkauan (data yang lebih kecil dari data data terkecil) dan selisihnya harus kurang dari panjang interval kelasnya. Selanjutnya dari sini dapat dibuat klasifikasi kelas/kategori.

\section{Pengaruh antar faktor pada aktivitas pemanfaatan rumput dan kayu bakar}

Analisis jalur merupakan suatu metode penelitian yang utamanya digunakan untuk menguji kekuatan dari hubungan langsung dan tidak langsung antara variable bebas (exogenous) terhadap variabel terikat (endogenous).

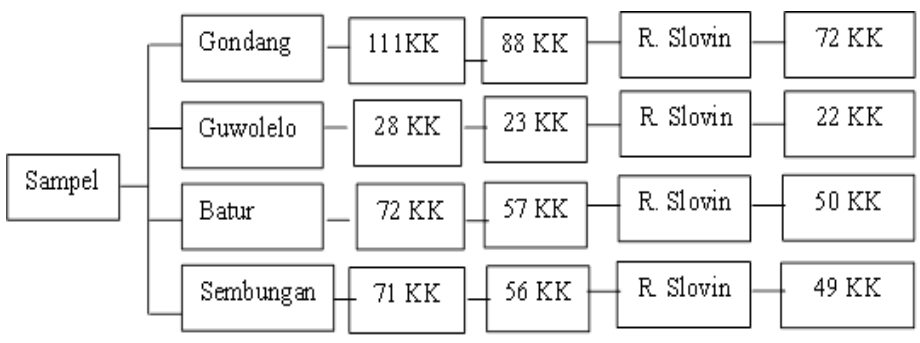

Gambar 1. Diskripsi pengambilan sampel 
Analisis jalur digunakan untuk menguji kemungkinan dari satu hubungan sebab akibat diantara tiga variabel atau lebih. Dengan demikian analisis jalur pada dasarnya adalah sarana untuk menganalisis hubungan kausal antar variabel guna mengetahui pengaruh langsung maupun pengaruh tidak langsung diantara variabel bebas terhadap variabel terikat. Analisis jalur terdiri dari empat langkah dasar, yaitu; (a) satu teori yang menghubungkan beberapa variabel yang dirumuskan untuk menjelaskan fenomena yang menjadi perhatian khusus, (b) variabel-variabel yang ditetapkan kemudian diukur dengan cara tertentu, (c) koefisien korelasi dihitung untuk menunjukkan kekuatan hubungan antara masingmasing pasangan variabel yang didalihkan, (d) hubungan koefisien korelasi dianalisis dalam hubungannya.

Secara matematis analisis jalur mengikuti model struktural yang ditentukan dengan seperangkat persamaan :

$\mathrm{Y}_{1}=\mathrm{F}_{1}\left(\mathrm{X}_{\mathrm{a}}, \ldots, \mathrm{X}_{\mathrm{q}} ; \mathrm{A}_{11}, \ldots, \mathrm{A}_{1 \mathrm{k}}\right)$

$\mathrm{Y}_{2}=\mathrm{F}_{2}\left(\mathrm{X}_{\mathrm{a}}, \ldots, \mathrm{X}_{\mathrm{q}} ; \mathrm{A}_{21}, \ldots, \mathrm{A}_{2 \mathrm{k}}\right)$

$Y_{p}=F_{p}\left(X_{a}, \ldots, X_{q} ; A_{p 1}, \ldots, A_{p k}\right)$

Persamaan ini mengisyaratkan hubungan kausal dari $X_{1}, X_{2}, \ldots X_{q}$ ke $Y_{1}, Y_{2}, \ldots, Y_{p}$. Apabila setiap variabel $\mathrm{Y}$ secara unique keadaannya ditentukan (disebabkan) oleh seperangkat variabel $\mathrm{X}$, maka persamaan diatas dinamakan persamaan struktural, dan modelnya disebut model struktural.

\section{Identifikasi Unsur Pembentuk Akses}

Ribot dan Peluso (2003) memformulasikan pengertian mengenai akses dan menjabarkannya secara lebih luas untuk dapat dibedakan dengan istilah 'hak'. Akses merupakan seluruh 'kemampuan' seseorang untuk dapat memperoleh manfaat dari sesuatu, sedangkan kepemilikan merupakan 'hak'. Unsur pembentuk akses meliputi unsur teknologi, modal, pasar, tenaga kerja, pengetahuan, kekuasaan, identitas sosial, dan negosiasi dari hubungan sosial dengan yang lain. Analisis unsur pembentuk akses disajikan dalam bentuk tabulasi.

\section{HASIL DAN PEMBAHASAN}

\section{Intensitas Pemanfaatan Rumput dan Kayu Bakar di Kawasan TNGMb}

Untuk mengetahui intensitas masyarakat dalam pemanfaatan rumput dan kayu bakar di TNGMb, digunakan metode statistik diskriptif (distribusi frekuensi). Dengan berdasarkan rekapitulasi data wawancara, diperoleh data jumlah total pengambilan rumput dan kayu bakar dari masing-masing dusun seperti pada Tabel 1.

\section{Intensitas pengambilan rumput dan kayu bakar}

Berdasarkan Tabel 1, maka diketahui nilai tertinggi untuk pengambilan rumput adalah 91,5, sedangkan nilai terendah untuk pengambilan rumput adalah 29. Dengan menggunakan Rumus Sturges, maka kategori kelas/distribusinya adalah jumlah kategori kelas $(k)=1+3.322 \log 4=2,99=$ 3 kelas/kategori. Dengan demikian dapat dibuat 3 kategori intensitas pengambilan rumput dari dalam kawasan menjadi kelas rendah, sedang, dan tinggi. Sedangkan interval kelas/kategori diperoleh dengan perhitungan sebagai berikut 20,83. Dengan demikian, maka dapat disusun kelas/kategori intensitas perumputan adalah:

Kelas rendah $=29-49,833$

Kelas sedang $=49,833-70,667$

Kelas tinggi $=70,667-91,5$

Jika nilai rata-rata pengambilan rumput adalah $63,375 \mathrm{kali} / \mathrm{hari}$, maka pengambilan rumput di TNGMb dikategorikan dalam kelas sedang cenderung tinggi.

\section{Intensitas pengambilan kayu bakar}

Berdasarkan Tabel 1 juga diketahui nilai tertinggi untuk pengambilan kayu bakar/ adalah 53, sedangkan nilai terendah untuk pengambilan kayu bakar/ adalah 20. Dengan menggunakan Rumus Sturges, maka kategori kelas/distribusinya adalah jumlah kategori kelas $(\mathrm{k})=1+3.322 \log 4=2,99=$ 3 kelas/kategori. Dengan demikian dapat dibuat 3 kategori intensitas pengambilan kayu bakar dari dalam kawasan menjadi kelas rendah, sedang, dan tinggi sebagaimana kelas pengambilan rumput. Sedangkan interval kelas/kategori pengambilan kayu bakar diperoleh $=11$. Dengan ini, maka dapat disusun kelas/kategori intensitas kayu bakar sebagai berikut:

Kelas rendah $=20-31$

Kelas sedang $=31-42$

Kelas tinggi $=42-53$

Jika nilai rata-rata pengambilan kayu bakar adalah 41,0625 kali/minggu, maka pengambilan kayu bakar di TNGMb dikategorikan dalam kelas sedang cenderung tinggi. Dari kelas/kategori perumputan dan pengambilan kayu bakar yang diperoleh, data bahwa kedua aktivitas tersebut dalam kelas sedang cenderung tinggi, maka Balai $\mathrm{TNGMb}$ sebagai pengelola sebaiknya mempertimbangkan aspek ekologi dan sosial dari kegiatan ini. Dampak ekologi dari aktivitas perumputan dan pengambilan kayu bakar, tentu berkorelasi dengan kelestarian kawasan. Semakin tinggi aktivitas perumputan dan pengambilan kayu bakar, maka kelestarian kawasan semakin menurun. Namun di sisi lain harus juga dipertimbangkan tingkat kebutuhan masyarakat sekitar kawasan terhadap rumput dan kayu bakar. 
Tabel 1. Frekuensi pengambilan rumput dan kayu bakar,

\begin{tabular}{|c|c|c|c|c|c|}
\hline Frekuensi $\quad$ Dusun & $\begin{array}{c}\text { Dusun } \\
\text { Gondang }\end{array}$ & $\begin{array}{c}\text { Dusun } \\
\text { Guwolelo }\end{array}$ & $\begin{array}{l}\text { Dusun } \\
\text { Batur }\end{array}$ & $\begin{array}{c}\text { Dusun } \\
\text { Sembungan }\end{array}$ & $\begin{array}{c}\text { Rata - rata } \\
\text { pengambilan }\end{array}$ \\
\hline $\begin{array}{l}\text { Pengambilan rumput } \\
\text { per hari }\end{array}$ & 91,5 & 29 & 65 & 68 & $63,375 \mathrm{kali} / \mathrm{hari}$ \\
\hline $\begin{array}{l}\text { Pengambilan kayu } \\
\text { bakar per minggu }\end{array}$ & 53 & 20 & 48,25 & 43 & 41,063 kali/minggu \\
\hline
\end{tabular}

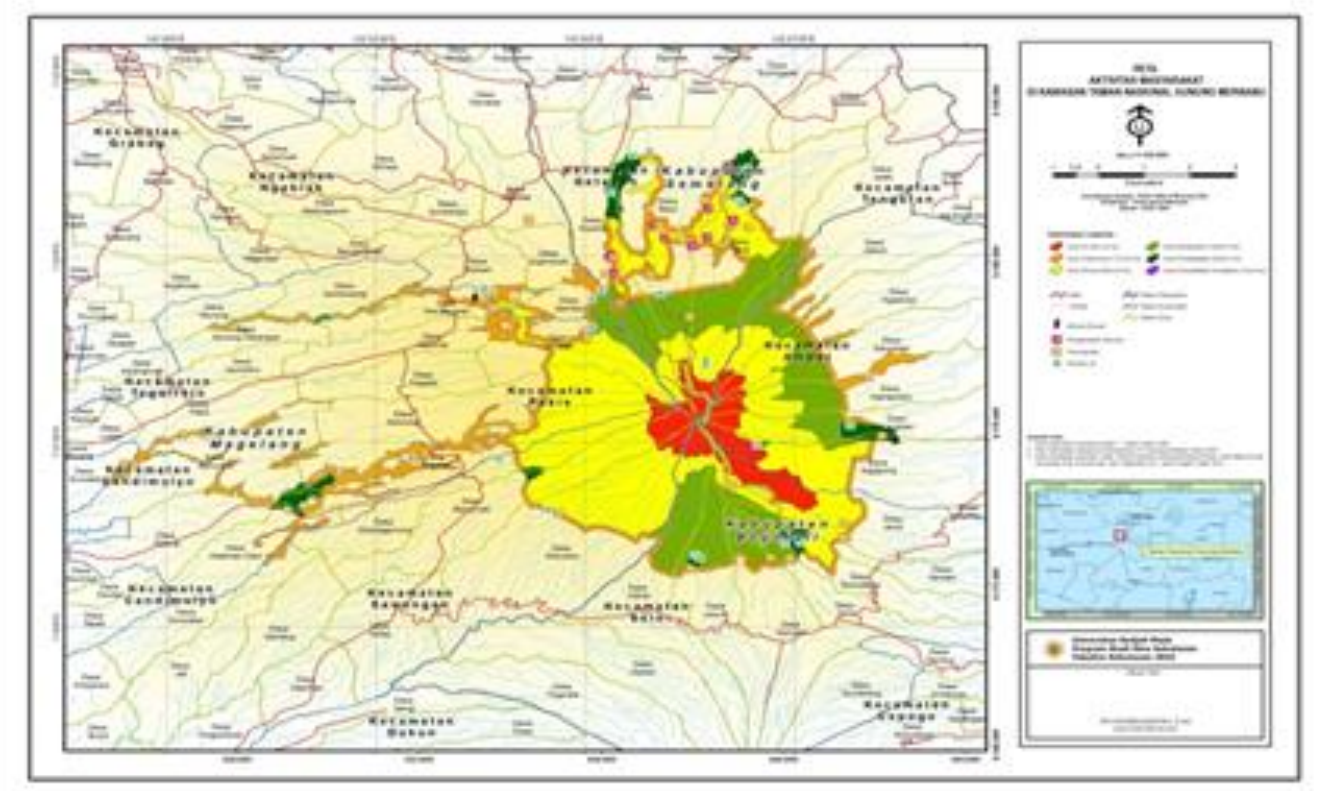

Gambar 2. Peta Aktivitas Masyarakat pada Zona Taman Nasional.

Pada Gambar 2 disajikan Peta Aktivitas Masyarakat pada Zona Taman Nasional Gunung Merbabu. Sebenarnya kawasan TNGMb ini pernah diusulkan untuk dilakukan klasterisasi ekosistem berdasarkan aspek biologis dan ekonomis (Hastuti dkk., 2011). Dalam hal perkembangannya untuk pengelolaan TNGMb ni tentu saja tetap harus mengikuti aturan terkait Kriteria Zona Pengelolaan Taman Nasional dan Blok Pengelolaan Cagar Alam, Suaka Margasatwa, Taman Hutan Raya, dan Taman Wisata Alam (Anonim, 2015).

\section{Pengaruh Antar Faktor pada Aktivitas Pemanfaatan Rumput dan Kayu Bakar}

Untuk mengetahui pengaruh antar faktor pada aktivitas pemanfataan rumput dan kayu bakar di $\mathrm{TNGMb}$, maka faktor-faktor dimaksud dikelompokkan dalam faktor budaya, faktor ekonomi, dan faktor kepemilikan lahan. Masingmasing faktor tersebut, mempunyai elemen dan variabel yang diukur dengan skala likert. Konversi skala likert dari sangat setuju, setuju, netral, kurang setuju, dan tidak setuju bervariasi dari angka 5, 4, 3, 2, dan 1. Kemudian masing-masing elemen penilaian dan variabelnya diuji reabilitas dan validitasnya dengan SPSS. Setelah diperoleh reabilitas tinggi dan validasinya baik, selanjutnya dilakukan analisis jalur (path analysis) dengan AMOS (Analysis of Moment Structure).

Analisis jalur (path analysis) merupakan metode yang mengkaji urutan sebab akibat antara sejumlah variabel dalam suatu model penelitian. Dengan kata lain, path analysis digunakan untuk menganalisis hubungan antar variabel dengan tujuan untuk mengetahui pengaruh langsung dan tidak langsung seperangkat variabel bebas (eksogen) terhadap variabel terikat (endogen). Tujuan analisis jalur adalah menerangkan akibat langsung dan tidak langsung seperangkat variabel, sebagai variabel penyebab, terhadap variabel lainnya yang merupakan variabel akibat (Sudaryono, 2011).

Pada penelitian ini dilakukan pengisian kuesioner oleh masyarakat dari dusun-dusun terpilih. Dengan asumsi bahwa $80 \%$ masyarakat di setiap dusun bersama-sama memanfaatkan rumput, rencek/ranting kering, dan air, maka dilakukan pengisian kuesioner secara acak berjumlah 193 responden. Variabel penilaian faktor budaya dalam penelitian ini mempunyai unsur nilai, kebiasaan, perayaan/event, dan kesenian. Variabel penilaian dari faktor ekonomi terdiri atas unsur pendapatan, kepemilikan ternak dan lahan pertanian, pengeluaran, serta kontribusi ekonomi terhadap kawasan. Sedangkan variabel penilaian dari faktor 


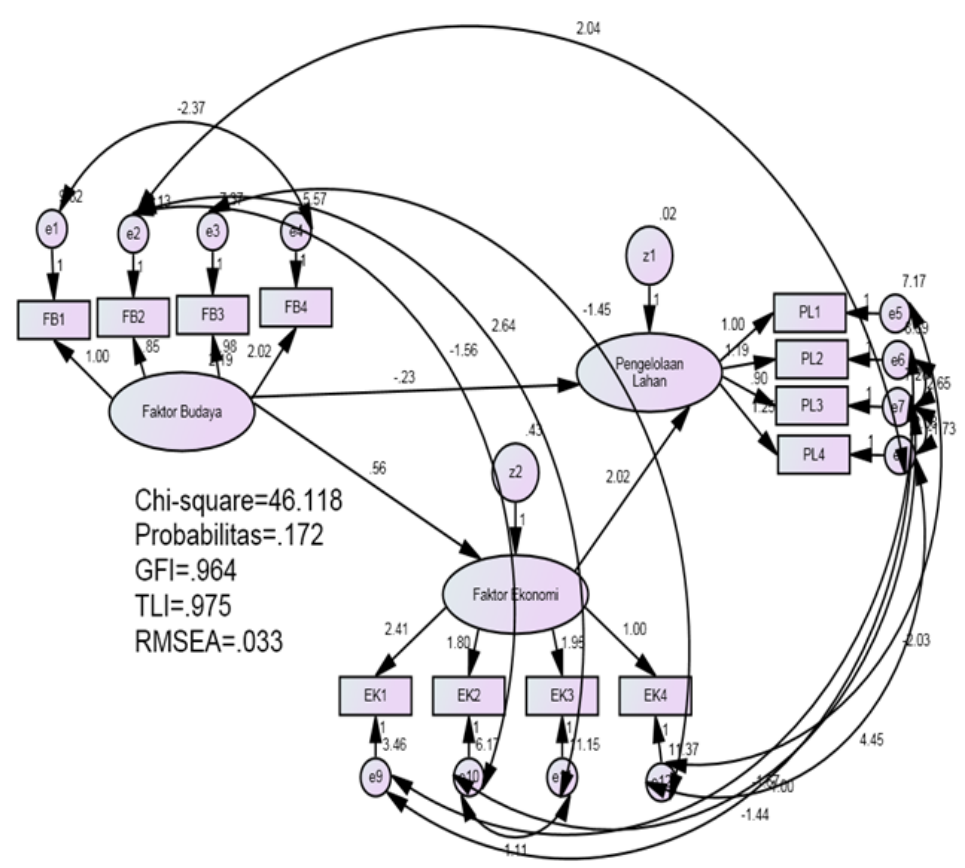

Gambar 3. Pengaruh budaya, ekonomi, dan pengelolaan lahan.

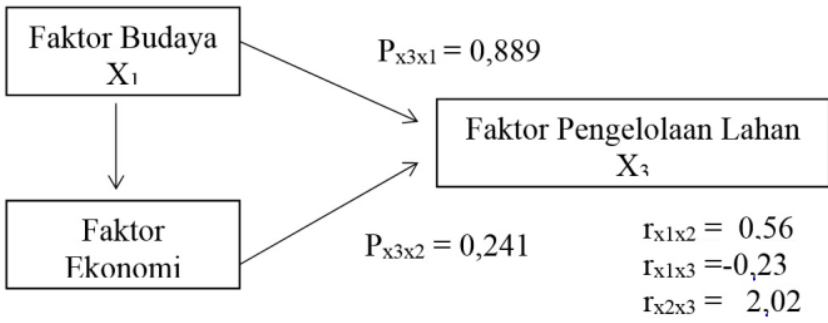

Gambar 4. Pengaruh antar faktor dalam membentuk aktivitas masyarakat.

pengelolaan lahan adalah lacen, status lacen, persepsi terhadap lacen, dan lahan pertanian di luar kawasan. Pengaruh antar faktor tersebut digambarkan dengan menggunakan analisis jalur (path analysis) seperti pada Gambar 3.

Data lapangan mengenai persepsi/sikap masyarakat terhadap tiga faktor yang ingin diuji, data kemudian dikonversi menjadi skala likert. Kemudian data dimaksud dilakukan pengujian validitas dan realibitasnya. Data dengan nilai corrected item-total correlation $>0,30$, maka item pertanyaan valid, jika cronbach's alpha > 0,6 maka data tersebut reliabel dan dapat diterima. Selanjutnya data diproses menggunakan analisis jalur (path analysis). Data yang dihasilkan memenuhi syarat untuk dilakukan uji path analysis karena chi square ( $\mathrm{p}=0.172>0.05)$, Goodness of Fit Index $>0.90$, Tucker Lewis Index 0.975>0.90 dan Root Mean Square Error Approximation <0.08.

Pada Gambar 3, dua arah panah menunjukkan hubungan korelasional, misalnya variabel e2 (kebiasaan) mempunyai hubungan korelasional dengan variabel e8 (pengelolaan lahan pertanian di luar kawasan). Intensitas keeratan hubungan ditunjukkan oleh angka koefisien di atas garis lengkung $(\mathrm{r}=2.04)$. Sedangkan satu arah panah menunjukkan hubungan kausal misalnya faktor budaya merupakan faktor eksogenus dari faktor ekonomi (faktor ekonomi menjadi faktor endogenus). Faktor budaya mempunyai koefisien jalur sebesar 0,889 secara langsung mempengaruhi faktor pengelolaan lahan. Faktor budaya secara tidak langsung (melalui faktor ekonomi) mempunyai koefisien jalur sebesar 0,241, sehingga faktor ekonomi dapat dijadikan sebagai variabel intervening (mediator) antara faktor budaya dengan faktor pengelolaan lahan. Berdasarkan perhitungan model summary, diperoleh koefisien residu $€$ sebesar 0,8705. Secara sederhana, pengaruh antar faktor dapat diilustrasikan pada Gambar 4.

Dengan data pada Gambar 4, maka diperoleh persamaan struktural sebagai berikut:

$\mathrm{X}_{3}=\mathrm{P}_{\mathrm{x} 3 \times 1}+\mathrm{P}_{\mathrm{x} 3 \mathrm{x} 2}+€=0,889 \mathrm{X}_{1}+0,241 \mathrm{X}_{2}+$ 0,8705 . Berdasarkan perhitungan tersebut, pengaruh parsial variabel eksogenus terhadap variabel endogenus dapat dihitung sebagai berikut: Untuk jalur $\mathrm{X}_{1}$ terhadap $\mathrm{X}_{3}$ :

a. Besarnya pengaruh langsung variabel $X_{1}$ terhadap variabel $\mathrm{X}_{3}$

$\mathrm{Px}_{3} \mathrm{X}_{1} \times \mathrm{Px}_{3} \mathrm{X}_{1}=0,889 \times 0,889=0,7903=$ $79,03 \%$

b. Besarnya pengaruh tidak langsung variabel $X_{1}$ terhadap variabel $\mathrm{X}_{3}$, melalui variabel $\mathrm{X}_{2}$

$\mathrm{Px}_{3} \mathrm{X}_{1} \times \mathrm{rx}_{1} \mathrm{X}_{2} \times \mathrm{Px}_{3} \mathrm{x}_{2}=0,889 \times 0,56 \times 0,241=$ $0,1199=11,99 \%$

c. Besarnya pengaruh total variabel $\mathrm{X}_{1}$ terhadap $\mathrm{X}_{3}$ 
$\left[\begin{array}{lllllll}\mathrm{Px}_{3} \mathrm{X}_{1} \mathrm{x} & \mathrm{P} & \mathrm{x}_{3} \mathrm{x}_{1}\end{array}\right]+\left[\begin{array}{lllll}\mathrm{Px}_{3} \mathrm{X}_{1} & \mathrm{x} & \mathrm{rx}_{1} \mathrm{x}_{2} & \mathrm{x} & \mathrm{Px}_{3} \mathrm{x}_{2}\end{array}\right]=$ $0,7903+0,1199=0,9102=91 \%$

Sebagai penjelasan berarti dengan demikian pengaruh faktor budaya $\left(X_{1}\right)$ terhadap faktor pengelolaan lahan $\left(\mathrm{X}_{3}\right)$, atau faktor pengelolaan lahan ditentukan oleh faktor budaya sebesar $91 \%$.

Untuk jalur $\mathrm{X}_{2}$ terhadap $\mathrm{X}_{3}$ :

a. Besarnya pengaruh langsung variabel $X_{2}$ terhadap variabel $\mathrm{X}_{3}$

$\mathrm{Px}_{3} \mathrm{X}_{2} \times \mathrm{P} \mathrm{X}_{3} \mathrm{X}_{2}=0,241 \times 0,241=0,058=5,8$ $\%$

b. Besarnya pengaruh tidak langsung variabel $X_{2}$ terhadap variabel $\mathrm{X}_{3}$, melalui variabel $\mathrm{X}_{1}$

$\mathrm{Px}_{3} \mathrm{X}_{2} \times \mathrm{rx}_{1} \mathrm{X}_{2} \times \mathrm{Px}_{3} \mathrm{X}_{1}=0,241 \times 0,56 \times 0,889=$ $0,1199=11,99 \%$

c. Besarnya pengaruh total variabel $\mathrm{X}_{2}$ terhadap $\mathrm{X}_{3}$

$\left[\begin{array}{llllllll}\mathrm{Px}_{3} \mathrm{x}_{2} & \mathrm{x} & \mathrm{P} & \mathrm{x}_{3} \mathrm{x}_{2}\end{array}\right]+\left[\begin{array}{lllll}\mathrm{Px}_{3} \mathrm{x}_{2} & \mathrm{x} & \mathrm{rx}_{1} \mathrm{x}_{2} \mathrm{x} & \mathrm{Px}_{3} \mathrm{x}_{1}\end{array}\right]=$ $0,058+0,1199=0,1779=17,8 \%$

Dengan demikian pengaruh faktor ekonomi $\left(\mathrm{X}_{1}\right)$ terhadap faktor pengelolaan lahan $\left(\mathrm{X}_{3}\right)$, atau faktor pengelolaan lahan ditentukan oleh faktor ekonomi sebesar $17,8 \%$.

Selanjutnya pengaruh bersama-sama (simultan) variabel eksogenus $\left(\mathrm{X}_{1}\right.$ dan $\left.\mathrm{X}_{2}\right)$ terhadap variabel endogenus $\left(\mathrm{X}_{3}\right)$ dapat dihitung sebagai berikut:

$\mathrm{R}^{2}{ }_{\mathrm{x} 3}(\mathrm{x1. \times 2})=\left(\mathrm{P}_{\mathrm{x} 3 \mathrm{x} 1} \mathrm{P}_{\mathrm{x} 3 \mathrm{x} 2}\right) \quad\left(\begin{array}{l}\mathrm{r}_{\mathrm{x} 1 \times 3} \\ \mathrm{r}_{\mathrm{x} 2 \times 3}\end{array}\right)=(0,8890,241)\left(\begin{array}{c}-0.23 \\ 2.02\end{array}\right)=0.2421$

Koefisien determinasinya adalah $\mathrm{R}_{\times 3}\left(\mathrm{x}_{1 . \times 2}\right)=\sqrt{ }$ $\mathrm{R}^{2} \times 3(\mathrm{x1. \times 2})=\sqrt{0}, 2421=0,492$. Dengan demikian pengaruh faktor budaya $\left(\mathrm{X}_{1}\right)$ dan faktor ekonomi $\left(X_{2}\right)$ secara bersama-sama terhadap faktor pengelolaan lahan, atau faktor pengelolaan lahan ditentukan oleh faktor budaya dan faktor ekonomi sebesar $49,2 \%$.

Dari hasil analisis jalur, diketahui bahwa faktor budaya secara langsung mempengaruhi faktor pengelolaan lahan. Faktor budaya dalam hal ini nilai, kebiasaan, perayaan/event, dan kesenian mempengaruhi masyarakat dalam mengelola lacen (lahan pemerintah yang ditanami masyarakat) dan lahan pertanian di luar kawasan. Pola seperti konsep lacen ini, dibahas juga di berbagai wilayah lain seperti dilaporkan oleh Schlager dan Ostrom (1992). Adanya nilai-nilai yang dianut sebagai kesepakatan bersama yang harus ditaati, mempengaruhi masyarakat dalam mengelola lacen. Masyarakat memperlakukan lacen sebagaimana kesepakatan dusun mengenai lacen, misalnya lacen hanya ditanami rumput, tidak melanggar batas, jika ada pelanggaran maka sanggup dikenakan sangsi, dan lain sebagainya.

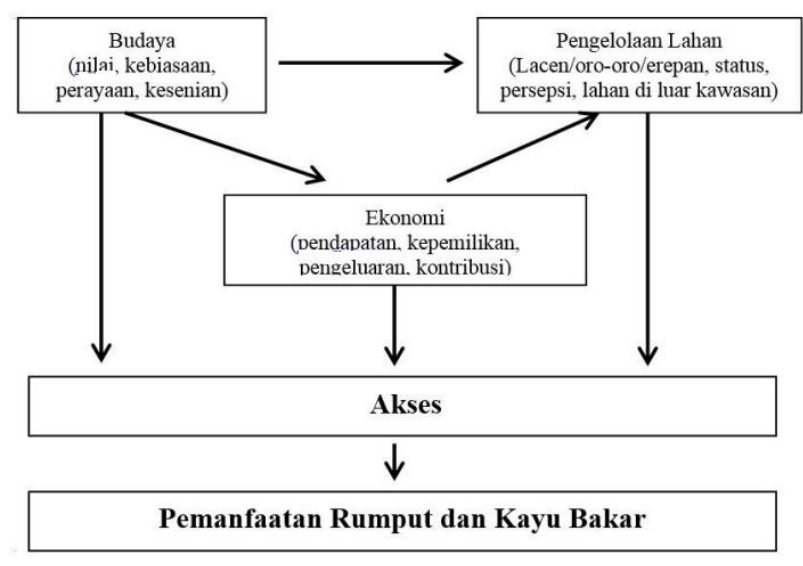

Hubungan antar faktor dengan akses.

Gambar 5. Hubungan antar faktor dengan akses.

\section{Unsur Pembentuk Akses}

Hubungan antar faktor berdasarkan path analysis membentuk akses masyarakat dalam pemanfaatan rumput dan kayu bakar, secara sederhana dapat dijabarkan seperti Gambar 5. Selanjutnya pada Tabel 2 disajikan hasil identifikasi unsur-unsur pembentuk akses pemanfaatan rumput dan kayu bakar dari Taman Nasional Gunung Merbabu:

Berdasarkan Tabel 2, dapat dijabarkan bahwa masyarakat yang memanfaatkan rumput dan kayu bakar dari kawasan, menggunakan teknologi atau peralatan sederhana/konvensional. Latar belakang masyarakat melakukan aktivitas dalam kawasan dikarenakan hal ini sudah menjadi budaya yang dianut secara turun temurun. Masyarakat lahir dan tinggal pada dusun yang berbatasan dengan kawasan, yang dimasa lalu orang tua mereka juga mencari pakan ternak, dan kayu bakar dari kawasan Merbabu secara bebas tanpa biaya atau gratis. Hal ini berlaku baik oleh masyarakat yang karena faktor kekerabatan mempunyai lacen dalam kawasan, maupun bagi masyarakat yang tidak mempunyai lacen dalam kawasan. Aktivitas pemanfaatan dilakukan secara mandiri (individu atau hanya dalam satu keluarga), tidak melibatkan tenaga kerja lain/pekerja, dan tidak diperjualbelikan. Hal ini menjadi ciri khas pemenuhan kebutuhan masyarakat secara subsisten seperti yang dikonsepkan oleh Morzillo dkk., (2015).

\section{KESIMPULAN}

Intensitas masyarakat sekitar kawasan Taman Nasional Gunung Merbabu dalam memanfaatkan rumput dan kayu bakar dalam kelas kategori sedang cenderung tinggi. Hal ini dipengaruhi oleh keberadaan lacen yakni klaim masyarakat atas hutan milik negara. 
Tabel 2. Unsur-unsur pembentuk akses.

\begin{tabular}{|c|c|c|}
\hline No & Unsur akses & Uraian \\
\hline 1 & Teknologi & $\begin{array}{l}\text { Masyarakat menggunakan teknologi konvensional/sederhana, misalnya dalam } \\
\text { pengambilan rumput dengan peralatan sabit, mengangkut rumput dengan tenaga } \\
\text { sendiri atau dengan bantuan sepeda motor, begitu juga dengan pengambilan kayu } \\
\text { bakar. }\end{array}$ \\
\hline 2 & Modal & $\begin{array}{l}\text { Modal dalam hal ini adalah perihal keistimewaan atau kekhususan dalam } \\
\text { mendapatkan akses, misalnya sewa, tiket masuk, biaya ijin dan lain-lain. } \\
\text { Masyarakat dalam memperoleh rumput dan kayu bakar di TNGMb secara } \\
\text { gratis/tidak membayar biaya apapun. }\end{array}$ \\
\hline 3 & Pasar & $\begin{array}{l}\text { Masyarakat sekitar kawasan tidak memerlukan pangsa pasar untuk memasarkan } \\
\text { rumput dan kayu bakar yang diperoleh dari kawasan. mengingat rumput dan kayu } \\
\text { bakar dimaksud digunakan untuk kebutuhan subsisten masyarakat, yaitu untuk } \\
\text { kebutuhan sendiri/keluarga dan tidak dijual/dikomersilkan. }\end{array}$ \\
\hline 4 & Tenaga kerja & $\begin{array}{l}\text { Dalam memperoleh rumput dan kayu bakar dari kawasan, masyarakat bekerja } \\
\text { dalam satuan keluarga. Mereka mencari rumput dan kayu bakar untuk dirinya } \\
\text { sendiri/keluarga. }\end{array}$ \\
\hline 5 & Pengetahuan & $\begin{array}{l}\text { Pengetahuan dalam memperoleh rumput dan kayu bakar identik dengan informasi. } \\
\text { Selain itu juga dibentuk oleh adanya faktor sosial, ritual budaya, kekerabatan, } \\
\text { kepercayaan, dan wacana. }\end{array}$ \\
\hline 6 & Kekuasaan & $\begin{array}{l}\text { Unsur kekuasaan mengandung pengertian adanya hukum atau perundang- } \\
\text { undangan yang dapat melarang aktor lain dalam memperoleh akses yang sama. } \\
\text { Adanya overlap kepentingan pada obyek yang sama, sering menimbulkan konflik } \\
\text { antar aktor. Masyarakat sekitar kawasan yang memanfaatkan rumput dan kayu } \\
\text { bakar tidak mempunyai kekuasaan untuk mengatur pihak lain dalam } \\
\text { memanfaatkan obyek yang sama. }\end{array}$ \\
\hline 7 & Identitas sosial & $\begin{array}{l}\text { Atribut sosial memberikan kesempatan kepada aktor (masyarakat) untuk } \\
\text { memperoleh manfaat dari rumput dan kayu bakar. Masyarakat yang tinggal pada } \\
\text { dusun yang berdekatan dengan kawasan, tempat lahir pada dusun tersebut, dan } \\
\text { tinggal pada dusun yang sama, maka akses untuk memperoleh rumput dan kayu } \\
\text { bakar secara otomatis melekat pada aktor yang bersangkutan. }\end{array}$ \\
\hline 8 & $\begin{array}{l}\text { Negosiasi dari } \\
\text { hubungan sosial } \\
\text { dengan yang lain }\end{array}$ & $\begin{array}{l}\text { Akses yang diperoleh karena hubungan pertemanan, timbal balik, patrilinear dan } \\
\text { lain-lain. Masyarakat di sekitar TNGMb memperoleh akses pemanfaatan rumput } \\
\text { dan kayu bakar karena hubungan patrilinear, dimana laki-laki sebagai kepala } \\
\text { rumah tangga memperoleh warisan terutama dalam mendapatkan hak waris lacen. }\end{array}$ \\
\hline
\end{tabular}

Pengaruh faktor budaya terhadap faktor pengelolaan lahan atau faktor pengelolaan lahan ditentukan oleh faktor budaya sebesar $91 \%$. Pengaruh faktor ekonomi terhadap faktor pengelolaan lahan atau faktor pengelolaan lahan ditentukan oleh faktor ekonomi sebesar 17,8 \%. Faktor ekonomi menjadi intervening factor/faktor mediasi antara faktor budaya dan faktor pengelolaan lahan. Pengaruh faktor budaya dan faktor ekonomi secara bersama-sama terhadap faktor pengelolaan lahan adalah sebesar 49,2\%.

Unsur pembentuk akses masyarakat sekitar kawasan dalam pemanfaatan rumput dan kayu bakar yang berasal dari Taman Nasional Gunung Merbabu bersifat sederhana atau konvensional baik dari segi teknologi, modal, pasar, tenaga kerja, pengetahuan, kekuasaan, identitas sosial, dan negosiasi dengan pihak lain. Hal ini menjadi ciri bahwa pemenuhan kebutuhan masyarakat sekitar kawasan Taman Nasional Gunung Merbabu akan rumput dan kayu bakar adalah secara subsisten.

\section{DAFTAR PUSTAKA}

Anonim, 2014. Zonasi Taman Nasional Gunung Merbabu (Dokumen Revisi Zonasi). Balai Taman Nasional Gunung Merbabu. Boyolali.

Anonim, 2015. Peraturan Menteri Lingkungan Hidup dan Kehutanan Nomor P.76/MENLHKSetjen/2015 tentang Kriteria Zona Pengelolaan Taman Nasional dan Blok Pengelolaan Cagar Alam, Suaka Margasatwa, Taman Hutan Raya, dan Taman Wisata Alam. Kementerian Kehutanan. Jakarta.

Adhikari, B., Di Falco, S., dan Lovett, J.C., 2003. Household Characteristics and Forest Dependency: Evidence from Common Property Forest Management in Nepal. Ecological Economics, 48:245-257.

Clements, T., Suon, S., Wilkie, D.S., dan MilnerGulland, E.J., 2014. Impacts of Protected Areas on Local Livelihoods in Cambodia. 
Journal of World Development, 64:S125S134.

Gunawan, H., Bismark, M., dan Krisnawati, H., 2013. Kajian Sosial Ekonomi Masyarakat Sekitar Sebagai Dasar Penetapan Tipe Penyangga Taman Nasional Gunung Merbabu, Jawa Tengah. Jurnal Penelitian Hutan dan Konservasi Alam 10(2):103-119.

Hastuti, D., 2010. Kajian Klasifikasi Ekosistem sebagai Dasar Pengelolaan Taman Nasional Gunung Merbabu. Disertasi. Fakultas Kehutanan, Universitas Gadjah Mada, Yogyakarta.

Hastuti, D., Marsono, D., Irham dan Sumardi, 2011. Klasterisasi Ekosistem Taman Nasional Gunung Merbabu Berdasarkan Aspek Biologis dan Sosial Ekonomi. J. Manusia \& Lingkungan, 18(2):85-97.

Morzillo, A.T., Colocousis, C.R., Munroe, D.K., Bell, K.P., Martinuzzi, S., van Berkel, D.B., Lechowicz, M.J., Rayfield, B., and McGill, B.,
2015. Communities in The Middle: Interactions Between Drivers of Change and Place-Based Characteristics in Rural ForestBased Communities. Journal of Rural Studies, 42:79-90.

Ribot, J.C; dan Peluso, N.L., 2003. A Theory of Access. Rural Sociology 68(2):153-181.

Schlager, E., dan Ostrom, E., 1992. Property Rights Regimes and Natural Resources: A Conceptual Analysis. Land Economics, 68(3):249-262.

Steele, M.Z., Scackleton, C.M., Shaanker, R.U., Ganeshaiah, K.N., dan Radolf, S., 2015. The Influence of Livelihood Dependency, Local Ecological Knowledge and Market Proximity on The Ecological Impacts of Harvesting NonTimber Forest Products. Forest Policy and Economics, 50:285-291.

Sudaryono, 2011. Aplikasi Analisis (Path Analysis) Berdasarkan Urutan Penempatan Variabel Dalam Penelitian. Jurnal Pendidikan dan Kebudayaan, 17(4):391-404. 